\title{
Developing Reading Task Evaluation Rubric to Identify Target Tasks for Particular Readers: An Analyzing Stage
}

\author{
Nina Suzanne ${ }^{1}$, Mukhaiyar ${ }^{2}$, Yenni Rozimela ${ }^{3}$ and Refnaldi ${ }^{4}$ \\ ${ }^{1234}$ Universitas Negeri Padang, Padang, Indonesia, $ه$ (email),nsuzanne.ns@gmail.com
}

\begin{abstract}
This study aims to develop a rubric of reading task evaluation. Task cannot be separated from reading comprehension activities. Usually, teachers or lecturers tend to give available tasks provided by the textbook or create their own. However, sometimes the tasks are not appropriate and not fulfill the readers' needs. Actually, a good task should consist of several components in order to achieve multiple outcome. Eventhough some experts have proposed the components of a good task and teachers can refer to the theories to check the task given, the appropriate and effective evaluation sheet is not available yet for them. Developing reading task evaluation rubric is a part of a research about developing reading tasks by using ADDIE model. Specifically, the rubric is developed based on several theories from some experts namely Nunan (2004), Cunningsworth (1995), Brown (2010), Elis (2003), etc. The product then is validated by two experts, revised and finally produced. The result of the research indicated that evaluating reading tasks in order to choose and create the good tasks is crucial to be done. Therefore, reading tasks evaluation rubric is needed to guide lecturers or teachers to do so. The rubric of reading task evaluation was developed with the following criteria, namely 1) goals and rationale, 2) input, 3) procedures, 4) task types, 5) teacher and learner roles, 6) setting, 7) implementation, 8) grading, 9) integration, and 10) assessment and evaluation. Furthermore, experts' judgments decided that the rubric and its components are valid and can be used to evaluate and choose the right reading tasks for the students. Finally, the result of reading tasks evaluation process by using the developed rubric will be an important information to develop a more appropriate reading comprehension tasks.
\end{abstract}

Keywords: Reading Task Evaluation, Rubric, Task Components, Target Tasks, Particular Readers

\section{INTRODUCTION}

Reading activities require readers to achieve comprehension as an evidence of their succeed in reading. Comprehension can be measured by answering several questions about the reading materials, rewriting the information obtained by using their own sentences, or sharing the ideas to others. Usually, in reading comprehension classroom, lecturers or teachers provide the students with reading tasks. The reading tasks can be taken from available textbooks, adopted, modified, or created by the lecturers themselves. In simple way, a task is a plan of work that is done or attempted. Some experts define task in similar way. Task is a communicative activities or workplan done by readers or learners which involves thought process to understand what they read or learn that is measurable and controlled by teachers for language learn and use and to achieve outcomes. (Nunan : 2007; Prabu in Mishan: 2005; Nunan in Mishan: 2005; Towndrow: 2007; Ellis: 2003)
Experience and preliminary research done have proved that lecturers tend to ignore the evaluation phase toward reading tasks. Actually, a task is made up by some elements. A minimum specification of tasks include the goals, input and steps, which are supported by roles and settings. (Nunan, 2004). Another opinion suggests task designers to consider several elements in constructing a good task, namely content, materials, activities, goals, students, and social community. (Shavelson and Stern in Nunan (2007). It seems that goals is one of important elements that provides direction for both given task and curriculum as a whole. Goals need to be considered when making a task due to the competence achievement as the target of doing the task. Another elements such as input, procedures, roles and setting also become important parts of a task.

The result of evaluating a task can be used as a need analysis for task-based language teaching. Tasks given could be different based on characteristics of 
learners or learners' diversity (Long, 2015). It is important to find out what learners can do in the new language. In the case of reading, of course learners need to identify, recognize, and understand what they read and express it orally or in written expression. Different readers' characteristics should be considered by teachers when designing lesson plans including tasks. (Zhang (2016) in Renandya and Widodo (2016). Instruction given will influence the reading process and how the readers reach their reading target.

Unfortunately, the need toward task-based reading activities which focus on student-centered is not supported by the presence of reading task evaluation rubric. It is a kind of evaluation sheet which consists of some aspects related to reading tasks and assessment space which make possible for lecturers or readers to identify whether the tasks chosen for their students are appropriate for them and support their needs in language learning or not. Rubric is usually used to evaluate activities (students' performance) or product (the quality of a report or educational resources) which includes evaluative criteria and merit determination (assessment@Carolina, 2017; Davidson in Oakden, 2013; Moscal in Yuan and Recker, 2015).

Several researches have been done due to evaluation rubric.Yuan and Recker (2015) did their research about rubrics used to evaluate the Open Educational Resources quality. They found that there is no standardized rubric. On the other hand, there are various rubrics can be used to identify the usability of activities or products, find out the educational utility by implementing varying amounts of user support.It means that, rubric can be constructed and developed based on the need. Munir and Nina (2017) also ever did a research about developing criteria of textbook evaluation. It is also in the form of rubric and they found that the developed product was valid to be used as a tool for textbook evaluation. Another research was done by Bernstein and Isaac (2018) who found that an evaluation rubric can be used for educational evaluation which encompasses two dimensions, namely demonstrates logic and reasoning and creative critical thought processes. It indicates that rubric is a usable tool for reading task evaluation that is developed in this research.

\section{METHOD}

This is Research and Development ( $\mathrm{R}$ and $\mathrm{D})$ which used ADDIE model to develop the product. ADDIE is a development model proposed by Branch (2009) which consists of five stages, namely analyze, design, develop, implement, and evaluate. The reading task evaluation rubric that was developed in this research is a part of analyze stage. The rubric as the developed product is constructed by following related theories and relevant studies such as Nunan (2007), Ellis (2003), Towndrow (2007), Brown (2010), Long (2015) for the content validity and Cunningsworth (1995), Munir and Nina (2017), and Sugiyono (2015) for construct validity. The product itself was then validated by experts in reading comprehension and instructional design by using validation sheet and experts judgments sheet. The result of evaluation toward reading tasks by using the developed rubric is a part of need analysis to develop reading comprehension tasks for particular groups of students based on their characteristics.

\section{RESULT AND DISCUSSION}

The reading task evaluation rubric is constructed in the form of a simple evaluation sheet which consists of three colums, 1) aspects, 2) scale, and 3) remarks. Aspects are 10 task components includes 42 indicators. Scale is the rate given based on the indicators that is divided into two, yes and no. It means that there are only two alternative for the condition of task being rate. No score is given because the evaluation purpose is not to judge whether the task is good or bad but to decide whether it is appropriate for the students or not. The scale is supported by remark in which evaluators/teachers could give explanation for their choice, yes or no. Experts judgement decided that this developed rubric is valid and can be used as an instrument to evaluate reading tasks. In general, the layout is in figure 1 .

\section{CRITERIA OF READING TASK EVALUATION \\ (Filled in by the researcher and colleague/Reading lecturer)}

Instruction: Fill in the following rubric by putting checklist $(\sqrt{ })$ on YES or No column and then write further explanation for the choice on REMARK column

\begin{tabular}{|c|c|c|c|}
\hline \multirow{2}{*}{ ASPECTS } & \multicolumn{2}{|c|}{ SCALE } & \multirow{2}{*}{ REMARK } \\
\hline & YES & NO & \\
\hline \multirow{3}{*}{$\begin{array}{l}\text { A. Goals and rationale } \\
\text { 1. Given explicitly } \\
\text { 2. Appropriate to the } \\
\text { learners' proficiency } \\
\text { level }\end{array}$} & & & \\
\hline & & & \\
\hline & & & \\
\hline \multicolumn{4}{|c|}{. .2019} \\
\hline \multicolumn{4}{|c|}{ Evaluator, } \\
\hline
\end{tabular}

Figure 1. Layout of reading evaluation

The developed reading task evaluation rubric can be seen in the following tables which is displayed for each aspect. First component of task included in the rubric is goals and rationale (See Table 1). There are 7 indicators to be rated. As it is explained earlier that goal is one crucial aspect to be considered in constructing or choosing a good tasks for the students. Goals provide a link between the task and the broader curriculum (Nunan, 2007). Sometimes it is better to express the goal explicitly. Goals can motivate the students to be more focus on their reading activity and be sure what to do.

Then, input (table 2) is the data or reading materials that the learners work with. It can be provided by teachers, textbooks or other sources such as articles from newspapers, magazines or journals, short stories, letters, memo notes, drama scripts, and so on. There are 6 indicators to be measured which includes the authenticity of the reading materials, the relevance, and the sources. 
Table 1. Goals and Rationale

\begin{tabular}{|c|c|c|c|}
\hline \multirow{2}{*}{ Aspects } & \multicolumn{2}{|c|}{ Scale } & \multirow{2}{*}{$\begin{array}{c}\text { Rem } \\
\text { ark }\end{array}$} \\
\hline & YES & NO & \\
\hline \multicolumn{4}{|l|}{ A. Goals and rationale } \\
\hline $\begin{array}{l}\text { 1. The goal of the task is given } \\
\text { explicitly }\end{array}$ & & & \\
\hline $\begin{array}{l}\text { 2. The task fits learners' proficiency } \\
\text { level }\end{array}$ & & & \\
\hline $\begin{array}{l}\text { 3. The goal of the task describes the } \\
\text { learner's role }\end{array}$ & & & \\
\hline $\begin{array}{l}\text { 4. The goal proposes the use of } \\
\text { language by learners }\end{array}$ & & & \\
\hline $\begin{array}{l}\text { 5. The goal proposes the language } \\
\text { learning process }\end{array}$ & & & \\
\hline $\begin{array}{l}\text { 6. The goal is focused on learner } \\
\text { performance }\end{array}$ & & & \\
\hline $\begin{array}{l}\text { 7. The task is interesting and motivates } \\
\text { students }\end{array}$ & & & \\
\hline
\end{tabular}

Table 2. Input

\begin{tabular}{cll}
\hline \multicolumn{1}{c}{ Aspects } & \multicolumn{1}{c}{ Scale } & Remark \\
B. & Input & \\
\hline 8. & $\begin{array}{l}\text { The reading materials are } \\
\text { authentic }\end{array}$ \\
\hline 9. & $\begin{array}{l}\text { The reading materials are non- } \\
\text { authentic (adapted, modified, etc) }\end{array}$ \\
\hline $\begin{array}{l}\text { 10. } \\
\text { The topics are suitable and } \\
\text { relevant for the learners }\end{array}$ \\
\hline $\begin{array}{l}\text { 11. } \\
\text { The reading materials are coming } \\
\text { from variety of resources (various } \\
\text { genres of reading) }\end{array}$ \\
\hline 12. The reading materials meet the \\
goal of tasks
\end{tabular}

Table 3. Procedures

\begin{tabular}{lll}
\hline \multicolumn{1}{c}{ Aspects } & \multicolumn{1}{c}{ Scale } & $\begin{array}{c}\text { Re } \\
\text { mar } \\
\text { ks }\end{array}$ \\
\hline C. Procedures & No \\
\hline 14. & $\begin{array}{l}\text { The classroom procedures mirror } \\
\text { communicative performance in the real } \\
\text { world }\end{array}$ \\
\hline 15. & $\begin{array}{l}\text { The activity supports learners' critical } \\
\text { thinking }\end{array}$ \\
\hline 16. & $\begin{array}{l}\text { The learners are engaged in problem- } \\
\text { solving activity }\end{array}$ \\
\hline 17. & $\begin{array}{l}\text { The reading task is designed for reading } \\
\text { skill getting }\end{array}$ \\
\hline 18. & $\begin{array}{l}\text { The reading task is constructed for } \\
\text { reading skill using }\end{array}$ \\
\hline 19. & $\begin{array}{l}\text { Developing learners' accuracy, fluency, } \\
\text { and complexity in applying reading skills }\end{array}$ \\
\hline 20. & Learners' activities are well-controlled \\
\hline 21. & $\begin{array}{l}\text { The reading task could stimulate students } \\
\text { to use bottom-up processing skills }\end{array}$ \\
\hline 22. & $\begin{array}{l}\text { The reading task is used to stimulate } \\
\text { students to use top-down processing } \\
\text { skills }\end{array}$ \\
\hline 23. & $\begin{array}{l}\text { The designed activities allow learners } \\
\text { communicate and cooperate in groups }\end{array}$ \\
\hline
\end{tabular}

Procedures mean what the readers will do with the input (reading materials). The procedures should mirror communicative performance in the real world and should focus on the message, not the medium. The purposes of reading should be the same in the class and as they are in the real life as well (Clark and Silberstein in Nunan, 2007). Procedures are closely related to reading skill getting or using, and support cooperation and communication in groups. In the rubric, there are 10 indictors for pocedure aspect.

Table 4. Task Types

\begin{tabular}{|c|c|c|}
\hline \multirow{2}{*}{ Aspect } & Scale & \multirow{2}{*}{$\begin{array}{l}\text { Rem } \\
\text { arks }\end{array}$} \\
\hline & Yes $\quad$ No & \\
\hline D. Task Types & & \\
\hline $\begin{array}{ll}\text { 24. } & \text { Proposing } \\
\text { reading (e.g cloze tasks, } \\
\text { impromptu reading plus } \\
\text { comprehension question, } \\
\text { scanning) }\end{array}$ & & \\
\hline $\begin{array}{l}\text { 25. } \\
\text { Proposing } \\
\text { extensive } \\
\text { reading (e.g } \\
\text { skimming, } \\
\text { notetaking, } \\
\text { summarizing) }\end{array}$ & & \\
\hline
\end{tabular}

The fourth task component written in the rubric is task types. Prabu in Nunan (2007) proposes three principles of task types, namely information gap activity (decoding or encoding information from or into languages, reasoning gap activity (getting new information inference or practical reasoning process), and opinion-gap activity (analyzing or evaluating information critically). While, Brown (2010) designs assessment reading task into four: perceptive (identifying letters, words, punctuation), selective (recognizing lexical, grammatical, or discourse features language within a very short stretch of language), interactive (readers interact with the text to identify relevant features within texts of moderately short length), and extensive (to tap into learners' global understanding of a text). However, in this rubric, the researcher only took two of them, interactive and extensive reading because the reading tasks are focused more on meaning, not form (topdown processing).

Table 5. Teacher and Learner Roles

\begin{tabular}{|c|c|c|c|c|}
\hline \multirow{2}{*}{\multicolumn{2}{|c|}{ Aspect }} & & & \multirow{2}{*}{$\begin{array}{c}\text { Rema } \\
\text { rks }\end{array}$} \\
\hline & & \multirow{2}{*}{ Yes } & \multirow[t]{2}{*}{ No } & \\
\hline E. & Teacher and Learner Roles & & & \\
\hline 26. & $\begin{array}{l}\text { The roles encourage the social } \\
\text { and interpersonal relationship } \\
\text { between the participants }\end{array}$ & & & \\
\hline & $\begin{array}{l}\text { Promoting characteristics of } \\
\text { good language learners (e.g } \\
\text { critical, reflective, and } \\
\text { autonomous) }\end{array}$ & & & \\
\hline 28. & $\begin{array}{l}\text { Promoting teachers' primary } \\
\text { roles in communicative } \\
\text { classroom (e.g facilitator, } \\
\text { participant, observer and } \\
\text { learner) }\end{array}$ & & & \\
\hline
\end{tabular}


Roles refer to the participation given by teacher and learners in carrying out the reading tasks. It is assumed that learners need to give contribution to the learning process. Good language learners including readers are critical, reflective and autonomous (Rubin and Thomson in Nunan: 2007). Teachers roles and learners roles are two side of a coin. Teachers should be more creative in order to support the learners to be more active when doing the tasks. There are three indicators in the rubric related to teacher and learners' roles.

Table 6. Setting

\begin{tabular}{|c|c|c|c|c|}
\hline \multirow{2}{*}{\multicolumn{2}{|c|}{ Aspect }} & \multicolumn{2}{|c|}{ Scale } & \multirow{2}{*}{ Remarks } \\
\hline & & yes & No & \\
\hline \multicolumn{5}{|c|}{ F. $\quad$ Setting } \\
\hline \multicolumn{5}{|c|}{$\begin{array}{l}\text { 29. Emphasizes on group- } \\
\text { based work }\end{array}$} \\
\hline \multicolumn{5}{|c|}{$\begin{array}{l}\text { 30. } \begin{array}{l}\text { Operating individual- } \\
\text { based work }\end{array} \\
\end{array}$} \\
\hline \multicolumn{5}{|c|}{$\begin{array}{ll}\text { 31. } & \text { Students do the task } \\
\text { inside the classroom }\end{array}$} \\
\hline \multicolumn{5}{|c|}{$\begin{array}{ll}32 . & \text { Students do the task } \\
\text { outside the classroom }\end{array}$} \\
\hline \multicolumn{5}{|c|}{$\begin{array}{l}\text { Setting is about when, where, and how the } \\
\text { learners do the tasks. Tasks sometimes are prepared to be } \\
\text { done wholly or partly in the classroom. It can be finished } \\
\text { well individually or in group. Nunan (2007) explains the } \\
\text { setting into two categories, mode (individually or group } \\
\text { work) and environment (classroom, community class, } \\
\text { learning centre, etc). }\end{array}$} \\
\hline
\end{tabular}

Table 7. Implementation

\begin{tabular}{ll}
\hline \multirow{2}{*}{ Aspect } & \multicolumn{2}{c}{ Scale } & \multirow{2}{*}{ Remarks } \\
\cline { 2 - 2 } G. Implementation & \\
\hline 33. & The task \\
engages the & \\
learners & \\
& interest \\
\hline 34. & The \\
& procedures \\
& support \\
& genuine \\
& communicati \\
& ve interaction \\
& among \\
& students \\
\hline 35. & The task \\
& stimulates the \\
& use of \\
& English \\
language well
\end{tabular}

A good reading task should be implemented in order to reach the target. Therefore, it is necessary to consider the learners' interest and what they expect to have by doing the tasks due to the use of English language for communication. The indicators for implementation aspect is three statements.
Table 8. Grading

\begin{tabular}{|c|c|c|c|}
\hline \multirow{2}{*}{ Aspect } & \multicolumn{2}{|c|}{ Scale } & \multirow{2}{*}{ Remarks } \\
\hline & Yes & No & \\
\hline \multicolumn{4}{|l|}{ H. Grading } \\
\hline $\begin{array}{l}\text { 36. } \begin{array}{l}\text { The task is relevant } \\
\text { to the students }\end{array} \\
\end{array}$ & & & \\
\hline 37. It is well-structured & & & \\
\hline
\end{tabular}

Grading concerns on the level of difficulty or complexity of reading input. It includes grammatical complexity, the length of the text, propositional density, the amount of low-frequecy vocabulary, the explicitness of the information, and the clarity and order of information (Nunan, 2007).

Table 9. Integration

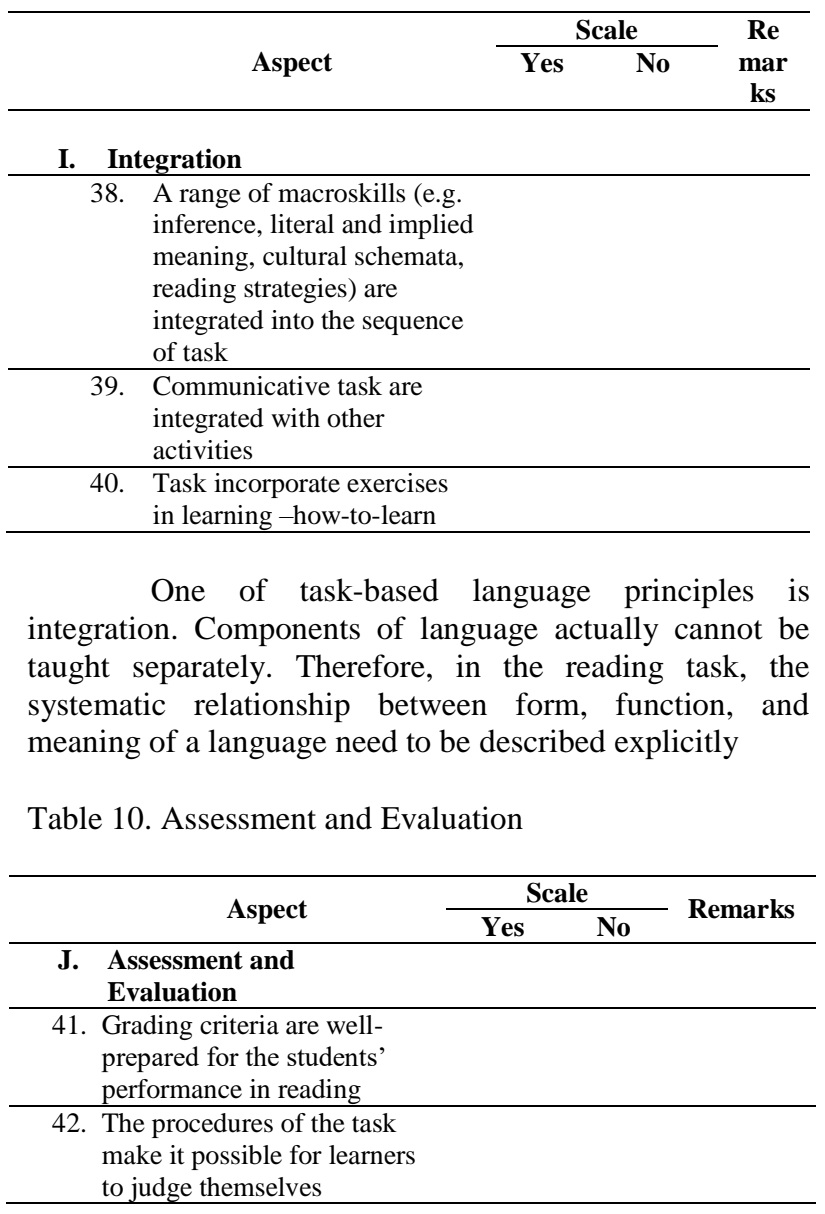

A good reading task should have exact grading criteria that can ease the work of teachers to score the students' performance. The assessment tool is reflected by the procedures of the tasks so the learners themselves can judge how well they can perform.

Components of tasks are very important to be considered in creating or choosing appropriate tasks for students. Tasks given to the students is expected to be one tool of finding out the students' need in learning. It is clear 
that tasks are activities that are prepared for the students to facilitate them to apply the language they learn through thinking process to reach the target. Some experts such as Wright in Nunan (2007) argues that at least, tasks contain only two elements, they are input data or the reading materials, and the initiating questions related to the materials. However, the two elements are not enough because the target is not a single intended outcome but multiple outcome. When reading a text, the target in not only to answer the questions given but also to apply the learned language in communicative classroom for preparing the real life use.

Ten aspects with 42 indicators which are included in the developed reading tasks evaluation rubric can guide teachers and lecturers to decide the good tasks for their students. The rubric is constructed in a common and simple way to make it easy to be used. For a wider and long-term used, of course the rubric itself cannot stand alone. It should be accompanied by rationale, manual, and also the sample. Evaluating reading tasks is not a complicated work and do not make teachers become more busy at all. On the other hand, it gives opportunity to them to know their students well and understand they need.

\section{CONCLUSION}

Reading tasks evaluation rubric is a guidance used by lecturers and teachers to choose the available tasks or create their own. It facilitates the achievement of reading activities outcome through tasks performance. The rubric that is developed in this research consists of 10 aspects including golas and rationale, input, procedures, setting, teacher and students roles, task types, implementation, grading, integration, and assessment and evaluation. Each aspect has indicators that are valid and effective to measure and observe the quality of a reading task.

\section{ACKNOWLEDGMENTS}

Alhamdulillahirabbil'alamin. The writers would like to thanks to anybody who have helped them with the study. First, their parents and all of family for the support mentally and physically. To the validators who have given comments and suggestions for a better product and also all of friends and collegues for the suggestion and pray.

\section{REFERENCES}

[1] Assessment@Carolina. (2017). Using Rubric to Assess Student Learning Outcomes at Program Level. The University of North Carolina at Chapel Hill

[2] Bernstein, Arla G. And Isaac, Carol. (2018). Critical Thinking Criteria for Evaluating Online Discussion. IJ-SoTL, Vol. 12 [2018], No. 2, Art. 11

[3] Branch, Robert Maribe. (2009). Instructional Design: The Addie Approach. New York: Springer.

[4] Brown, H. Douglas. 2001. Teaching by Principles: An Interactive Approach to Language Pedagogy $2^{\text {nd }}$ edition. New York : Longman.
[5] Brown, H. Douglas and Priyanvada Abeywickrama. (2010). Language Assessment: Principles and Classroom Practices. Second edition. Longman: Pearson Education, Inc.

[6] Cunningsworth, A. (1995). Choosing Your Coursebook. Oxford: Heinemann Publishers Ltd.

[7] Ellis, Rod. (2003). Task-based Language Learning and Teaching. New York: Oxford University Press.

[8] Long, Mike. (2015). Second language Acquisition and Task-based language Teaching. West Sussex: John Wiley and Sons Ltd

[9] Mishan, Freda. (2005). Designing Authenticity into Language Learning Materials. Bristol: Intellect Books

[10]Munir, Sirajul and Suzanne, Nina. (2017). Developing Criteria of An English Textbook Evaluation. Penelitian. Batusangkar: IAIN Batusangkar

[11]Nunan, David. (2004). Task-Based Language Teaching: A Comprehensively revised edition of Designing Tasks for the Communicative Classroom. Cambridge: Cambridge University Press

[12] Oakden, Judy. (2013). Evaluation Rubrics: How to Ensure Transparent and Clear Assessment that Respects Diverse Lines of Evidence. Better Evaluation - www.betterevaluation.org

[13] Renandya, Willy A. and Handoyo Puji Widodo. (2016). English Language Teaching Today. Linking Theory and Practice.

[14] Sugiyono. (2015). Metode Penelitian dan Pengembangan. Research and Development. Untuk Bidang pendidikan, manajemen, sosial dan teknik. Bandung: Alfabeta.

[15] Towndrow, Phillip A. (2007). Task Design, Implementation, and Assessment. Integrating information and communication technology in English language teaching and learning. McGrawHill Education (Asia)

[16] Yuan, Min and Recker, Mimi. (2015). Not All Rubrics Are Equal: A Review Of Rubrics For Evaluating The Quality Of Open Educational Resources. International Review of Research in Open and Distributed Learning. Volume 16, Number 5

[17] Zhang, Lawrence Jun. (2016). Teaching Reading and Viewing to L2 Learners in Renandya, Willy A. and handoyo Puji Widodo. (2016). English Language Teaching Today. Linking Theory and Practice. Springer International Publishing Switzerland. 